\title{
PENETAPAN POLA REHABILITASI PEMULIHAN FUNGSI EKOSISTEM HUTAN LINDUNG GAMBUT SUNGAI BRAM ITAM DI KABUPATEN TANJUNG JABUNG BARAT, PROVINSI JAMBI
}

\author{
(Determining Rehabilitation Patterns for Recovery of Sungai Bram Itam Peatland \\ Protected Forest Ecosystem Functions Tanjung Jabung Barat District, Jambi Province) \\ Dhany Yuniati ${ }^{1}$, Dodik Ridho Nurrochmat ${ }^{2}$, Syaiful Anwar ${ }^{3}$ dan/and Darwo ${ }^{1}$ \\ ${ }^{1}$ Pusat Penelitian dan Pengembangan Hutan \\ Jl. Gunung Batu No.5 Po Box 165 Bogor, Jawa Barat, Indonesia Telp. 0251-8633234; Fax 0251-8638111 \\ ${ }^{2}$ Departemen Silvikultur, Fakultas Kehutanan IPB \\ Jl. Lingkar Kampus IPB, Dramaga Bogor 16680, Jawa Barat, Indonesia \\ ${ }^{3}$ Departemen Ilmu Tanah dan Sumber, Fakultas Pertanian IPB \\ Jl. Ulin, Babakan, Dramaga, Bogor, Jawa Barat 16680, Jawa Barat, Indonesia \\ E-mail: dhanyyuniati@yahoo.co.id; syaianwar@yahoo.com
}

Tanggal diterima: 9 Mei 2018; Tanggal direvisi: 28 Mei 2018; Tanggal disetujui: 31 Mei 2018

\begin{abstract}
An area of 5,000 hectares in the Bram Itam River peatland protected forest had been converted into agricultural land and plantations dominated by oil palm, pinang and liberica coffee plantations. This land conversion has led to destruction of its function as a protected forest, thus recovery action must be performed. The study aimed to establish a pattern of vegetation rehabilitation on peatlands with damaged protected functions by prioritizing native peatland species and considering land suitability, environmental aspect, and socio-economic conditions. The aspects that were analyzed including the socio-economic conditions of the community, the status and function of the area, the consequences of rehabilitation activities, the characteristics of peatland, and the type of preference for rehabilitation. Data was collected through a survey method of forest farmer groups that manage the land area around Sungai Bram Itam protected area. The results indicated that community around the study area are in need of farm lands. Its status as protected forest with various land characteristics requires management zoning to facilitate the community's need for land. Social forestry program with a partnership scheme can be applied to areas adjacent to community land with peat depth less than $2 \mathrm{~m}$. The planting method that should be applied is mixed cropping pattern of native species and plantation crops, which considers the protection function. Area with peat depth more than $2 \mathrm{~m}$ should be managed by KPHL Sungai Bram Itam to maintain and improve the protection function by planting native peatland species.
\end{abstract}

Key words: Peatland conversion, palm oil, areca nut, liberica coffee, revegetation

\begin{abstract}
ABSTRAK
Seluas 5.000 hektare areal hutan lindung gambut Sungai Bram Itam telah mengalami alih fungsi menjadi lahan pertanian dan perkebunan yang didominasi oleh perkebunan sawit, pinang, dan kopi liberika. Alih fungsi menyebabkan kerusakan fungsi lindung sehingga harus dilakukan pemulihan. Penelitian bertujuan untuk menetapkan pola rehabilitasi vegetasi pada lahan gambut dengan fungsi lindung yang telah mengalami kerusakan. Pemulihan fungsi lindung dilakukan dengan rehabilitasi vegetasi menggunakan jenis asli gambut dan mempertimbangkan kesesuaian lahan, aspek lingkungan, sosial-ekonomi. Aspek-aspek yang dianalisis adalah kondisi sosial ekonomi masyarakat, status dan fungsi kawasan, konsekuensi terhadap kegiatan rehabilitasi, karakteristik lahan gambut, dan preferensi jenis untuk rehabilitasi. Data dikumpulkan melalui metode survei terhadap kelompok tani hutan yang melakukan pengelolaan lahan di areal HLG Sungai Bram Itam. Hasil penelitian menunjukkan bahwa masyarakat di sekitar HLG Sungai Bram Itam membutuhkan lahan garapan. Status HLG Sungai Bram Itam sebagai kawasan dengan fungsi lindung dan memiliki karakteristik lahan yang beragam memerlukan penataan zonasi pengelolaan untuk memfasilitasi kebutuhan masyarakat terhadap lahan. Pada kawasan dengan kedalaman gambut $<2 \mathrm{~m}$ yang berbatasan dengan lahan masyarakat bisa dilakukan program perhutanan sosial dengan skema kemitraan. Pola tanam yang diterapkan berupa pola tanam campuran antara jenis tanaman hutan asli gambut dengan tanaman perkebunan (kopi liberika, pinang, dan MPTS) yang tetap memperhatikan fungsi lindung. Lahan gambut dengan kedalaman $>2$ m dikelola oleh pihak
\end{abstract}


KPHL Sungai Bram Itam untuk mempertahankan dan memperbaiki fungsi lindung melalui penanaman jenis tanaman asli gambut.

Kata kunci: Alih fungsi lahan gambut, pinang, kopi liberika, revegetasi

\section{PENDAHULUAN}

Kawasan Hutan Lindung Gambut (HLG) Sungai Bram Itam merupakan kawasan hutan yang mempunyai fungsi lindung pada Kesatuan Hidrologis Gambut (KHG) Sungai Batara-Sungai Mendahara. Fungsi lindung ekosistem gambut adalah tatanan unsur gambut yang memiliki karakteristik tertentu yang mempunyai fungsi utama dalam perlindungan dan keseimbangan tata air, penyimpan cadangan karbon, dan pelestarian keanekaragaman hayati untuk dapat melestarikan fungsi ekosistem gambut (KemenLHK, 2017). Dengan demikian, sesuai dengan Keputusan Presiden No. 32 Tahun 1990 tentang Pengelolaan Kawasan Lindung pada kawasan dengan fungsi lindung dilarang untuk melakukan kegiatan budidaya, kecuali yang tidak mengganggu fungsi lindung.

Namun pada kenyataannya, sebagian kawasan HLG Sungai Bram Itam telah mengalami alih fungsi. Diperkirakan 5.000 ha dari 15.050 ha arealnya telah beralih fungsi menjadi lahan pertanian dan perkebunan (KPHL, 2017). Alih fungsi yang dominan adalah untuk perkebunan kelapa sawit (Elaeis guineensis Jacq.), pinang (Areca catechu L.), dan kopi liberika (Coffea liberica Hiern). Pada kegiatan alih fungsi tersebut, dilakukan pembuatan kanal-kanal untuk mengalirkan air. Di samping itu, kegiatan alih fungsi cenderung mengurangi penutupan lahan yang luasannya terus meningkat. Banyaknya drainase buatan dan terjadinya pengurangan penutupan lahan merupakan indikator kerusakan fungsi lindung ekosistem gambut (KemenLHK, 2017). Kondisi lahan gambut yang demikian memerlukan upaya pemulihan fungsi ekosistem.
Pemulihan fungsi ekosistem gambut adalah aktivitas yang dilakukan untuk mengembalikan sifat dan fungsi ekosistem gambut sesuai atau mendekati sifat dan fungsi semula (KemenLHK, 2017). Salah satu upaya pemulihan fungsi ekosistem gambut dilakukan melalui rehabilitasi vegetasi yakni dengan penanaman vegetasi/revegetasi (replanting), sehingga produktivitas dan peranannya dalam mendukung sistem penyangga kehidupan tetap terjaga (KemenLHK, 2017).

Penelitian ini bertujuan untuk menetapkan pola rehabilitasi vegetasi pada lahan gambut dengan fungsi lindung yang telah mengalami kerusakan. Rehabilitasi vegetasi tersebut dilakukan dengan mengutamakan jenis asli gambut dan mempertimbangkan berbagai aspek yaitu kesesuaian lahan, lingkungan, sosial, dan ekonomi (KemenLHK, 2017). Untuk mengakomodir hal-hal tersebut, maka dalam menetapkan pola rehabilitasi perlu dilakukan analisis terkait kondisi sosial ekonomi masyarakat, status, dan fungsi kawasan serta konsekuensi terhadap kegiatan rehabilitasi, karakteristik lahan gambut, preferensi jenis tanaman untuk rehabilitasi vegetasi, karakteristik, pertimbangan teknis, dan nilai ekonomi dari jenis tanaman asli gambut. Penelitian ini diharapkan dapat menjadi bahan pertimbangan dalam melakukan pemulihan fungsi ekosistem gambut dengan fungsi lindung, sehingga manfaat ekologi, ekonomi, dan sosial dari lahan gambut dapat tercapai.

\section{METODOLOGI}

\section{A. Waktu dan Lokasi Penelitian}

Penelitian dilakukan pada bulan September sampai dengan November 2017 di HLG Sungai Bram Itam Kabupaten Tanjung Jabung Barat Provinsi Jambi. HLG Sungai Bram Itam berada di 
Dhany Yuniati, Dodik Ridho Nurrochmat, Syaiful Anwar dan Darwo

bawah pengelolaan KPHL Sungai Bram Itam.

\section{B. Metode}

\section{Pengumpulan data}

Sumber data yang digunakan adalah data primer dan data sekunder yang diperoleh dengan cara: (1) observasi atau pengamatan langsung di lapangan, (2) wawancara dengan melakukan komunikasi langsung kepada responden menggunakan kuisioner, (3) pencatatan semua data sekunder dari instansi yang terkait dengan penelitian, (4) studi literatur dengan mengumpulkan data dari berbagai sumber antara lain jurnal, buku, hasil penelitian, prosiding, atau tulisan ilmiah lainnya.

Responden penelitian adalah masyarakat yang melakukan kegiatan alih fungsi lahan di hutan lindung gambut Sungai Bram Itam. Obyek penelitian dipilih secara purposive yakni kelompok tani hutan $(\mathrm{KTH})$ yang telah melakukan pengelolaan lahan di HLG Sungai Bram Itam. Hasil pendataan oleh KPHL Sungai Bram Itam terdapat 213 kepala keluarga yang melakukan pemanfaatan lahan dan tergabung ke dalam enam KTH. Penentuan sampel dilakukan secara simple random sampling dari daftar anggota KTH. Sampel yang diambil sebanyak 33 responden. Untuk mengetahui karakteristik lahan gambut di lokasi penelitian dilakukan pengamatan langsung di lapangan dengan melakukan pengambilan sampel di beberapa titik untuk mewakili kondisi lahan gambut yang ada.

\section{Analisis data}

a. Kondisi sosial ekonomi masyarakat

Aspek yang dianalisis meliputi karakteristik kependudukan dan pola pengelolaan lahan. Aspek-aspek tersebut dianalisis secara kualitatif untuk menggambarkan kondisi sosial ekonomi masyarakat yang melakukan pemanfaatan lahan di kawasan HLG Sungai Bram Itam. b. Status dan fungsi kawasan serta konsekuensi terhadap pengelolaan untuk rehabilitasi vegetasi dianalisis dengan menggunakan "content analysis" terhadap:

(1) Peraturan Pemerintah No. 6 Tahun 2007 jo PP no 3 Tahun 2008 tentang Tata Hutan dan Penyusunan Rencana Pengelolaan Hutan serta Pemanfaatan Hutan

(2) Permen LHK No. P.16/MenLHK /Set-jen/Kum.1/2/2017 tentang Pedoman Teknis Pemulihan Fungsi Ekosistem Gambut.

c. Karakteristik lahan gambut

Karakteristik lahan gambut yang dianalisis meliputi: jenis dan kedalaman gambut. Analisis dilakukan secara kualitatif terkait parameter yang diambil untuk menentukan zonasi pengelolaan kawasan.

d. Preferensi jenis tanaman untuk rehabilitasi vegetasi.

Preferensi jenis meliputi tanaman pertanian dan perkebunan. Data dianalisis dengan menggunakan tabulasi silang dan penapisan (screening) dengan kriteria: bukan jenis invasif, bukan jenis dengan konsumsi air yang tinggi, jenis dengan intensitas pengelolaan yang rendah.

e. Karakteristik dan pertimbangan teknis serta nilai ekonomi dari jenis tanaman asli gambut

Data hasil penelitian terkait jenisjenis tanaman yang dapat tumbuh di lahan gambut dan dokumen hasil invetarisasi jenis tanaman asli gambut di areal HLG Sungai Bram Itam dianalisis dengan menggunakan tabulasi silang. Dari jenisjenis yang ditemukan, kemudian dilakukan screening terkait kemudahan mendapatkan bibit dan nilai ekonomi dari tanaman. 


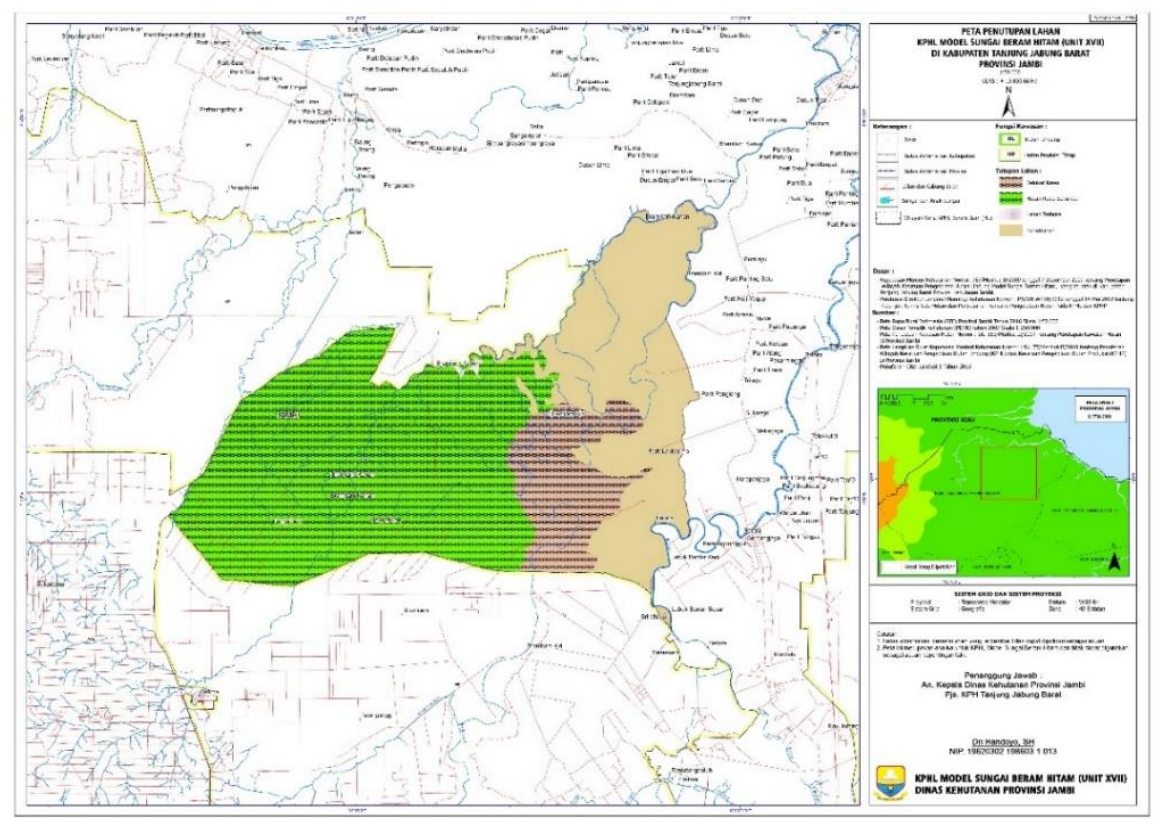

Sumber/Sources: (KPHL, 2017)

Gambar (Figure) 1. Peta kawasan Hutan Lindung Gambut di KPHL Sungai Bram Itam, Provinsi Jambi (Map of protected peatland forest in KPHL Sungai Bram Itam, Jambi Province)

\section{HASIL DAN PEMBAHASAN}

\section{A. Hasil}

\section{Kondisi sosial ekonomi dan budaya masyarakat}

Masyarakat Kabupaten Tanjung Jabung Barat pada umumnya dan masyarakat di sekitar HLG Sungai Bram Itam khususnya, sebagian besar adalah masyarakat pendatang dari luar Pulau Sumatera (KPHL, 2017). Beberapa suku pendatang tersebut diantaranya suku-suku Jawa, Banjar, Minang, Bugis, Batak, Lampung, Riau, dan Aceh yang datang melalui program transmigrasi maupun swadaya (Irawanti et al., 2017). Hal ini sejalan dengan hasil inventarisasi yang dilakukan oleh BPKH XIII Pangkal Pinang pada tahun 2010 yang menunjukkan bahwa 56,7\% masyarakat di sekitar maupun di dalam areal KPHL Sungai Bram Itam merupakan pendatang dari daerah Bugis, Jawa, Melayu, dan Banjar (KPHL, 2017).

HLG Sungai Bram Itam secara administrasi terletak di tiga kecamatan yaitu Kecamatan Pengabuan, Betara, dan Bram Itam dan meliputi sepuluh desa yakni Desa Bram Itam Raya, Bram Itam Kanan, Serdang Jaya, Bunga Tanjung, Mekar Jaya, Mandala Jaya, Karya Maju, Sungai Baung, Teluk Nilau, dan Suak Saman. Jumlah penduduk pada kecamatan di wilayah pengelolaan KPHL Sungai Bram Itam dan perkembangannya selama kurun waktu 2010 sampai 2015 disajikan pada Tabel 1.

Sebagian besar masyarakat yang bertempat-tinggal dan beraktivitas di sekitar lokasi HLG Sungai Bram Itam adalah petani $(76,7 \%)$ dan lainnya adalah buruh tani, guru, pedagang, dan tukang kayu (KPHL, 2017).

Pada saat ini, terdapat area seluas \pm 5.000 ha dari kawasan HLG Sungai Bram Itam yang telah dikelola oleh masyarakat dengan rata-rata penguasaan lahan per orang adalah 3,11 ha (KPHL, 2017). Data hasil pengamatan di enam kelompok tani hutan disajikan pada Tabel 3.

Masyarakat memanfaatkan lahan HLG Sungai Bram Itam untuk kegiatan 
agroforestri, monokultur pertanian, dan monokultur perkebunan, tetapi beberapa petani belum menanami lahan garapannya (Irawanti et al., 2017). Pada lahan yang sudah digarap, pola pemanfaatan lahan yang dilakukan adalah ditanami dengan (a) sawit, jagung; (b) pinang, jagung; (c) sawit, pinang, jagung; dan (d) pinang, kopi. Dari pemanfaatan lahan tersebut, masyarakat pada umumnya tidak menggunakan bibit yang bersertifikat, jarang melakukan pemupukan serta hanya melakukan pemeliharaan tanaman yang minimal.

Tabel (Table) 1. Jumlah penduduk, kepadatan, dan laju pertumbuhan penduduk kecamatan di kawasan kelola HLG Sungai Bram Itam (Total population, density and rate of population growth of sub-districts in the protected peatland forest of Sungai Bram Itam)

\begin{tabular}{cccccc}
\hline No. & $\begin{array}{c}\text { Kecamatan } \\
\text { (Subdistricts })\end{array}$ & $\begin{array}{c}\text { Luas wilayah } \\
(\text { Total area }) \\
\left(\mathrm{km}^{2}\right)\end{array}$ & $\begin{array}{c}\text { Penduduk } \\
(\text { Population }) \\
(\text { Orang/Persons })\end{array}$ & $\begin{array}{c}\text { Kepadatan } \\
\text { penduduk } \\
(\text { Population } \\
\text { density }) \\
\left(\text { Orang } / \mathrm{km}^{2}\right)\end{array}$ & $\begin{array}{c}\text { Laju pertumbuhan } \\
\text { penduduk }(\text { Rate of } \\
\text { population growth }) \\
(\% \text { per tahun }) \\
(\% \text { per years })\end{array}$ \\
\hline 1. & Bram Itam & 312,66 & 15.438 & 49 & 0,94 \\
2. & Pengabuan & 440,13 & 25.142 & 57 & 1,45 \\
3. & Betara & 570,21 & 27.972 & 49 & 3,34 \\
\hline
\end{tabular}

Sumber (Source): Badan Pusat Statistik Kabupaten Tanjung Jabung Barat tahun 2016

Tabel (Table) 2. Mata pencaharian masyarakat di sekitar kawasan HLG Bram Itam (Community's livelihoods around protected peatland forest of Sungai Bram Itam)

\begin{tabular}{lcccccc}
\hline $\begin{array}{l}\text { Pekerjaan } \\
(\text { Occupation })\end{array}$ & $\begin{array}{c}\text { Petani } \\
(\text { Farmer }) \\
(\%)\end{array}$ & $\begin{array}{c}\text { Guru } \\
(\text { Teacher }) \\
(\%)\end{array}$ & $\begin{array}{c}\text { Pedagang } \\
(\text { Trader }) \\
(\%)\end{array}$ & $\begin{array}{c}\text { Buruh tani } \\
(\text { Farm } \\
\text { workers }) \\
(\%)\end{array}$ & $\begin{array}{c}\text { Nelayan } \\
(\text { Fisherman }) \\
(\%)\end{array}$ & $\begin{array}{c}\text { Tukang } \\
\text { kayu } \\
(\text { Carpenter }) \\
(\%)\end{array}$ \\
\hline $\begin{array}{l}\text { Utama (Main } \\
\begin{array}{l}\text { occupation) } \\
\text { Sampingan (Side } \\
\text { occupation) }\end{array}\end{array}$ & 76,70 & 10,00 & 3,00 & - & - & 1,00 \\
\hline
\end{tabular}

Sumber (Source): Dinas Kehutanan Kabupaten Tanjung Jabung Barat (2015)

Tabel (Table) 3. Penguasaan lahan anggota kelompok tani hutan di dalam kawasan HLG Sungai Bram Itam (Land tenure of forest farmer groups in protected peatland forestof Sungai Bram Itam area)

\begin{tabular}{llccc}
\hline No & $\begin{array}{c}\text { Kelompok tani (Farmer } \\
\text { groups) }\end{array}$ & $\begin{array}{c}\text { Luas lahan } \\
\text { (Total area) (ha) }\end{array}$ & $\begin{array}{c}\text { Jumlah anggota } \\
\text { (Number of } \\
\text { members) } \text { (orang) }\end{array}$ & $\begin{array}{c}\text { Rata-rata penguasaan } \\
\text { lahan (Average land } \\
\text { holding) (ha) }\end{array}$ \\
\hline 1. & Bonne Makkamase & 122,57 & 43 & 2,85 \\
2. & Jawa Bugis Mega buana & 91,59 & 21 & 4,36 \\
3. & Pattiro Jaya & 111,40 & 32 & 3,48 \\
4. & Pada 'Idi Sidomakmur & 149,93 & 43 & 3,49 \\
5. & Bekawan Raya & 127,38 & 43 & 2,96 \\
6. & Jelutung Mutiara & 60,50 & 31 & 1,95 \\
& Jumlah & 663,37 & 213 & 3,11 \\
\hline Sumber (Source):
\end{tabular}

Sumber (Source): $\quad$ Rencana Pengelolaan Hutan Jangka Panjang KPHL Sungai Bram Itam (2017) 
Tabel (Table) 4. Pola pemanfaatan lahan oleh masyarakat di areal HLG Sungai Bram Itam (community land utilization patterns of in protected peatland forest of Sungai Bram Itam)

\begin{tabular}{|c|c|c|c|c|}
\hline \multirow[b]{2}{*}{$\begin{array}{l}\text { Pola pemanfaatan } \\
\text { (Pattern of land use) }\end{array}$} & \multicolumn{3}{|c|}{ Komposisi } & \multirow[b]{2}{*}{$\begin{array}{l}\text { Keterangan } \\
\text { (Remark) }\end{array}$} \\
\hline & $\begin{array}{c}\text { Sawit } \\
\text { (Palm oil) } \\
\text { (Batang) } \\
\text { (Stand) }\end{array}$ & $\begin{array}{l}\text { Pinang } \\
\text { (Areca nut) } \\
\text { (Batang) } \\
\text { (Stand) }\end{array}$ & $\begin{array}{c}\text { Kopi liberika } \\
\text { (Liberica coffee) } \\
\text { (Batang) } \\
\text { (Stand) }\end{array}$ & \\
\hline $\begin{array}{l}\text { Sawit (palm oil/ E. } \\
\text { guineensis), jagung } \\
\text { (corn/Zea mays L.) }\end{array}$ & $130-150$ & - & - & $\begin{array}{l}\text { Jarak tanam sawit } \\
\text { (palm oil spacing) } 9 \\
\text { x } 8 \mathrm{~m}\end{array}$ \\
\hline $\begin{array}{l}\text { 2. Sawit (palm oil/ E. } \\
\text { guineensis), pinang } \\
\text { (areca nut/A. } \\
\text { catechu), jagung } \\
\text { (corn/Z. mays) }\end{array}$ & 125 & 495 & & $\begin{array}{l}\text { Jarak tanam pinang } \\
\text { (areca nut spacing) } \\
3 \times 3 \mathrm{~m} \text {, sawit (palm } \\
\text { oil) } 9 \times 9 \mathrm{~m}\end{array}$ \\
\hline $\begin{array}{l}\text { 3. Pinang (areca nut/ A. } \\
\text { catechu), jagung } \\
\text { (corn/Z. mays) }\end{array}$ & - & 1075 & - & $\begin{array}{l}\text { Jarak tanam pinang } \\
\text { (areca nut spacing) } \\
3 \times 3 \mathrm{~m}\end{array}$ \\
\hline $\begin{array}{l}\text { 4. Pinang (areca nut/A. } \\
\text { catechu), kopi } \\
\text { liberika (liberica } \\
\text { coffee/C. liberica) }\end{array}$ & - & 580 & 500 & $\begin{array}{l}\text { Jarak tanam kopi } \\
\text { liberika(liberica } \\
\text { coffee spacing) } 3 \times 3 \\
\text { m dan pinang (areca } \\
\text { nut) } 3 \times 3 \mathrm{~m}\end{array}$ \\
\hline
\end{tabular}

Sumber (Source): Hasil wawancara (Interview result)

\section{Status dan fungsi kawasan HLG Sungai Bram Itam}

HLG Sungai Bram Itam merupakan kawasan hutan dengan fungsi lindung sesuai dengan surat keputusan Menteri Kehutanan dan Perkebunan No. 421/KptsII/1999. Berdasarkan Peraturan Pemerintah No.6 Tahun 2007 jo PP no 3 Tahun 2008 tentang Tata Hutan dan Penyusunan Rencana Pengelolaan Hutan serta Pemanfaatan Hutan bahwa pada kawasan hutan dengan fungsi lindung, pemanfaatan hanya bisa dilakukan terhadap Hasil Hutan Bukan kayu (HHBK) dan jasa lingkungan. Lebih lanjut dijelaskan, pemanfaatan tersebut dapat dilakukan dengan ketentuan: tidak mengurangi, mengubah, atau menghilangkan fungsi utamanya, pengolahan tanah terbatas, tidak menimbulkan dampak negatif terhadap biofisik dan sosial ekonomi, tidak menggunakan peralatan mekanis dan alat berat, serta tidak membangun sarana dan prasarana yang mengubah bentang alam. Kegiatan usaha pemanfaatan jasa lingkungan pada hutan lindung, dilakukan dengan ketentuan tidak: mengurangi, mengubah, atau menghilangkan fungsi utamanya, mengubah bentang alam, dan merusak keseimbangan unsur-unsur lingkungan.

Terkait dengan pemulihan fungsi ekosistem gambut dengan rehabilitasi vegetasi, maka diutamakan menggunakan tanaman jenis asli setempat seperti yang tercantum dalam lampiran PP No.6 tahun 2007. Salah satu kriteria keberhasilan pemulihan fungsi ekosistem gambut apabila jumlah tanaman yang tumbuh sehat paling sedikit lima ratus batang/hektare pada tahun ketiga (KemenLHK, 2017).

\section{Karakteristik lahan gambut di HLG Sungai Bram Itam}

Berdasarkan pengamatan tentang karakteristik lahan gambut di beberapa tempat di lokasi penelitian disajikan pada Tabel 5. 
Dhany Yuniati, Dodik Ridho Nurrochmat, Syaiful Anwar dan Darwo

Tabel (Table) 5. Karakteristik lahan gambut di HLG Sungai Bram Itam (Characteristics of peatlands in protected peatland forest of Sungai Bram Itam)

\begin{tabular}{|c|c|c|c|}
\hline $\begin{array}{l}\text { Titik pengeboran } \\
\text { (Points of drilling ) }\end{array}$ & $\begin{array}{l}\text { Kedalaman } \\
\text { (Depth) } \\
(\mathrm{cm})\end{array}$ & $\begin{array}{c}\text { Kematangan } \\
\text { gambut } \\
\text { (Peat maturity) }\end{array}$ & $\begin{array}{c}\text { Posisi tinggi muka air tanah (Position } \\
\text { of ground water level ) }\end{array}$ \\
\hline Titik (Point) 1 & $\begin{array}{l}0-25 \\
25-50 \\
50-60 \\
60-100\end{array}$ & $\begin{array}{l}\text { Saprik (Saprist) } \\
\text { Hemik (Hemist) } \\
\text { Fibrik (Fibrist) } \\
\text { Mineral (Mineral) }\end{array}$ & $\begin{array}{l}\text { Muka air tanah (Ground water level) } \\
- \\
- \\
-\end{array}$ \\
\hline Titik (Point) 2 & $\begin{array}{l}0-25 \\
25-50 \\
50-60 \\
60-100\end{array}$ & $\begin{array}{l}\text { Saprik (Saprist) } \\
\text { Hemik (Hemist) } \\
\text { Fibrik (Fibrist) } \\
\text { Mineral (Mineral) }\end{array}$ & $\begin{array}{l}- \\
\text { Muka air tanah (Ground water level) } \\
-\end{array}$ \\
\hline Titik (Point) 3 & $\begin{array}{l}0-25 \\
25-50 \\
50-60 \\
60-100\end{array}$ & $\begin{array}{l}\text { Saprik (Saprist) } \\
\text { Hemik (Hemist) } \\
\text { Fibrik (Fibrist) } \\
\text { Mineral (Mineral) }\end{array}$ & $\begin{array}{l}- \\
\text { Muka air tanah (Ground water level) } \\
-\end{array}$ \\
\hline $\begin{array}{l}\text { Hutan Alam } \\
\text { (Natural forest) }\end{array}$ & $\begin{array}{l}0-25 \\
\\
25-50 \\
50-60 \\
60-100 \\
100-130 \\
130-150 \\
150-200\end{array}$ & $\begin{array}{l}\text { Saprik (Saprist) } \\
\\
\text { Hemik (Hemist) } \\
\text { Fibrik (Fibrist) } \\
\text { Fibrik (Fibrist) } \\
\text { Fibrik (Fibrist) } \\
\text { Mineral (Mineral) } \\
\text { Mineral (Mineral) }\end{array}$ & Muka air tanah (Ground water level) \\
\hline Titik (Point) 4 & $\begin{array}{l}0-25 \\
25-50 \\
50-75 \\
75-100\end{array}$ & $\begin{array}{l}\text { Saprik (Saprist), Hemik } \\
\text { (Hemist), Fibrik } \\
\text { Mineral (Mineral) } \\
\text { Mineral (Mineral) } \\
\text { Mineral (Mineral) }\end{array}$ & $\begin{array}{l}\text { Muka air tanah (Ground water level) } \\
22-23 \mathrm{~cm} \\
- \\
- \\
-\end{array}$ \\
\hline
\end{tabular}

Sumber (Source): (Darwo et al., 2017)

Data di atas diperkuat oleh dokumen RPHJP KPH Sungai Bram Itam bahwa formasi geologi di areal HLG Sungai Bram Itam adalah endapan rawa dengan jenis tanah utama adalah jenis tanah gambut (histosol). Kedalaman/ ketebalan gambut berkisar antara 0,5 sampai $7 \mathrm{~m}$ atau dengan kata lain termasuk dalam kategori lahan gambut dengan kedalaman dangkal sampai sangat dalam. Tingkat kematangan gambut di areal HLG berbeda-beda meliputi gambut mentah (fibrist), gambut setengah matang (hemist) sampai gambut matang (saprist) (KPHL, 2017).
4. Preferensi jenis-jenis yang dikembangkan oleh masyarakat di HLG Sungai Bram Itam

Dari hasil wawancara diperoleh informasi tentang preferensi masyarakat terhadap tanaman asli gambut untuk rehabilitasi vegetasi yang disajikan pada Tabel 6.

Preferensi masyarakat terhadap tanaman perkebunan/pertanian untuk rehabilitasi vegetasi lahan gambut disajikan pada Tabel 7. 
Tabel (Table) 6. Preferensi masyarakat terhadap tanaman asli gambut pada rehabilitasi vegetasi di HLG Sungai Bram Itam (People's preferences for native peatland specieson vegetation rehabiliation at protected peatland forestof Sungai Bram Itam)

\begin{tabular}{|c|c|c|}
\hline $\begin{array}{l}\text { Jenis yang dipilih } \\
\text { (Selected species) }\end{array}$ & $\begin{array}{l}\text { Persentase } \\
(\text { Percentage })\end{array}$ & $\begin{array}{l}\text { Alasan } \\
\text { (Reason) }\end{array}$ \\
\hline 1. Jelutung (Dyera polyphylla (Miq.) Steenis) & $6 \%$ & $\begin{array}{l}\text { Anjuran pemerintah (Goverment } \\
\text { suggestion) }\end{array}$ \\
\hline $\begin{array}{l}\text { 2. Punak (Tetramerista glabra Miq.) medang } \\
\text { (Litsea sp.), meranti (Shorea } \mathrm{sp.)}\end{array}$ & $18 \%$ & Diambil kayunya (produce timber) \\
\hline $\begin{array}{l}\text { 3. Matoa (Pometia pinnata), rambutan } \\
\text { (Nephelium lappaceum L), mangga } \\
\text { (Mangifera indica L.), duku (Lansium } \\
\text { parasiticum (Osbeck) K.C.Sahni \& Bennet), } \\
\text { manggis (Garcinia mangostana L.), pala } \\
\text { (Myristica fragrans Houtt), jengkol } \\
\text { (Archidendron pauciflorum (Benth.) } \\
\text { I.C.Nielsen), kemiri (Aleurites moluccanus } \\
\text { (L.) Willd.), petai (Parkia speciosa Hassk.), } \\
\text { dan durian (Durio zibethinus L.) }\end{array}$ & $48 \%$ & $\begin{array}{l}\text { Buahnya bernilai ekonomi (Fruit } \\
\text { with economic value) }\end{array}$ \\
\hline 4. Tidak tahu (not know) & $15 \%$ & $\begin{array}{l}\text { Tidak mengenal tanaman asli gambut } \\
\text { (Unfamiliar with native peat plants) }\end{array}$ \\
\hline 5. Tidak mau (unwilling) & $13 \%$ & $\begin{array}{l}\text { Tidak bernilai ekonomi (No } \\
\text { economic value ) }\end{array}$ \\
\hline
\end{tabular}

Sumber (Source): Hasil wawancara (Interview result)

Tabel (Table) 7. Preferensi masyarakat terhadap tanaman pertanian/perkebunan pada rehabilitasi vegetasi lahan gambut di HLG Sungai Bram Itam (People's preferences for agricultural crops/plantations on vegetation rehabilitation at protected peatland forest of Sungai Bram Itam)

\begin{tabular}{lcl}
\hline \multicolumn{1}{c}{$\begin{array}{c}\text { Jenis yang dipilih } \\
\text { (Selected species) }\end{array}$} & $\begin{array}{c}\text { Persentase } \\
\text { (Percentage })\end{array}$ & \multicolumn{1}{c}{$\begin{array}{c}\text { Alasan } \\
\text { (Reason) }\end{array}$} \\
\hline 1. Pinang (areca nut/A. catechu L) & $94 \%$ & $\begin{array}{l}\text { Permintaan pasar tinggi (High } \\
\text { market demand) } \\
\text { Paling mudah dipasarkan (Most } \\
\text { easily marketed) }\end{array}$ \\
2. Sawit (palm oil/E. guineensis) & $78 \%$ & $\begin{array}{l}\text { Harga dipasaran tinggi (High } \\
\text { market price) } \\
\text { 3rospek pasarnya kembali bagus } \\
\text { 3. Kopi liberika (liberica coffee/C. liberica) }\end{array}$ \\
4. Kelapa hibrida (hybrid coconut/Cocos \\
$\begin{array}{l}\text { nucifera } \text { L.) } \\
\text { (Mimproving) }\end{array}$
\end{tabular}

Sumber (Source): Hasil wawancara (Interview result)

\section{Karakteristik dan pertimbangan teknis serta nilai ekonomi dari jenis tanaman asli gambut}

Dalam silvikultur lahan gambut, dikenal istilah paludikultur. Paludikultur adalah silvikultur alternatif untuk agribisnis lahan gambut konvensional (Schäfer, 2012). Jenis-jenis alami yang yang dapat tumbuh di lahan gambut merupakan jenis yang dapat menyesuaikan dengan kondisi basah karena memiliki lentisel dan sistem perakaran yang telah teradaptasi membentuk struktur akar nafas atau disebut dengan pneumatophores (Tata \&, Pradjadinata, 2017).

Beberapa spesies yang tumbuh di hutan rawa gambut di Propinsi Kalimantan Tengah antara lain: kayu arang (Diospyros pilosanthera Blanco), medang suluh (Neoscortechinia philippinensis (Merr.) Welzen), medang (Litsea angulata Blume), perupuk (Acronychia 
Dhany Yuniati, Dodik Ridho Nurrochmat, Syaiful Anwar dan Darwo

porteri Hook.f.,) Endiandra sp., mentibu (Dactylocladus stenostachys Oliv.), pasirpasir (Stemonurus scorpioides Becc.), perepat (Combretocarpus rotundatus Miq.), jambu-jambu (Syzygium sp.), nyatoh (Palaquium pseudorostratum H.J.Lam) (Sidiyasa, 2012). Sagu (Metroxylon sago Rottb.) adalah salah satu dari sedikit tanaman tropis yang bisa ditolerir pada kondisi tempat tumbuh basah, termasuk rawa gambut (Karim, Tie, Manan, \& Zaidul, 2008). Purun tikus (Eleocharis dulcis Hensch.) merupakan tanaman air yang ditemukan rawa gambut (Prihatini Priatmadi, Masrevaniah, \& Soemarno, 2016) dan potensial untuk biofilter karena dapat tumbuh dengan baik pada kondisi $\mathrm{pH}$ yang rendah (Prihatini et al., 2016). Ramin (Gonystylus bancanus (Miq.) Kurz) merupakan kayu yang memiliki kualitas tinggi yang tumbuh di rawa gambut dan terancam secara legal atau ilegal untuk ditebang (Yule, 2010). Gerunggang (Cratoxylum arborescens (Vahl) Blume.) merupakan pohon yang dominan yang ditemukan di hutan rawa gambut sekunder di Tumbang Nusa Kalimantan Tengah (Sosilawaty, Yanarita, \& Andrean, 2017). Jelutung rawa (D. polyphylla) merupakan spesies asli tanaman hutan gambut dan memberikan alternatif yang menarik bagi masyarakat dari sisi tenaga kerja dibandingkan kelapa sawit karena menghasilkan upah yang lebih tinggi yaitu US \$ 16,46 per hari dibandingkan sawit yang hanya US \$16,06 (Giesen, 2015). Hutan rawa gambut di Sarawak dan Brunei didominasi terutama oleh Dipterocarpaceae endemik yakni Shorea albida Sym., sedangkan hutan rawa gambut di Kalimantan bagian selatan ditemukan jenis kayu balangeran (Shorea balangeran (Korth.) Burck.) (Posa Wijedasa, \& Corlett, 2011). Gelam (Melaleuca sp.) adalah spesies rawa pasang surut yang banyak tumbuh di hutan rawa gambut di Kalimantan Selatan dan
Kalimantan Tengah. Jenis ini merupakan salah satu spesies yang potensial sebagai kayu penghasil asap cair (Alpian, Prayitno, Pramana, Sutapa, \& Budiadi, 2014).

Hasil inventarisasi yang dilakukan KPHL (2017) mendapatkan bahwa di areal HLG Sungai Bram Itam ditemukan 32 jenis pohon endemik di rawa gambut. Spesies yang dominan ditemukan adalah ramin (Gonystylus bancanus (Miq.) Kurz), jelutung rawa (D. polyphylla), punak ( $T$. glabra), rengas (Gluta rengas Hook.f.), resak (Vatica sp.), meranti (Shorea spp.), kelat (Eugenia spp.), dan kempas (Koompassia excelsa (Becc.) Taub.). Spesies kayu penghasil buahbuahan yang dapat dikonsumsi baik oleh hewan maupun manusia juga ditemukan antara lain manggis hutan (Garcinia spp.), dan rambutan hutan (Spondias sp.) (KPHL, 2017).

Saat ini tidak semua jenis tanaman asli gambut bibitnya dapat diperoleh dengan mudah. Penangkar bibit di Kabupaten Tanjung Jabung Barat kebanyakan hanya menyediakan jelutung rawa (D. polyphylla). Jenis lain yang bisa diperoleh dari penangkar di Kabupaten Tanjung Jabung Timur dan Kota Jambi adalah punak (T. glabra), kelat (Eugenia sp.), medang putih (Litsea sp.), medang mangga (Litsea sp.), laban (Vitex sp.), manggis-manggisan (Illex cymosa Blume), dan jambu-jambu (Syzygium sp.). Jenis balangeran (Shorea balangerans Burck) harus didatangkan dari Palembang atau Kalimantan Selatan. Hal ini menjadi kendala dalam kegiatan rehabilitasi vegetasi lahan gambut di HLG Sungai Bram Itam. Selain kendala teknis ketersediaan bibit, terdapat pula kendala ekonomi. Tercatat 1.376 jenis tanaman di kawasan hutan gambut dataran rendah di Asia Tenggara, hanya 534 (38.8\%) jenis tanaman yang telah diketahui pemanfaatannya, diantaranya penghasil kayu (222 jenis), obat-obatan (121), 
makanan (165 jenis, seperti buah-buahan, biji, dan minyak). Dari jumlah tersebut, 81 jenis merupakan hasil hutan bukan kayu yang merupakan sumber perekonomian utama (Giesen, 2015).

\section{B. Pembahasan}

Kegiatan alih fungsi untuk kegiatan budidaya pertanian dan perkebunan di kawasan HLG Sungai Bram Itam dilakukan dengan membuka lahan gambut dan membuat kanal-kanal untuk mengalirkan air. Pembuatan drainase merupakan salah satu penyebab rusaknya sifat kimia, fisika, dan biologi tanah gambut. Kerusakan sifat kimia, fisika, dan biologi lahan gambut merupakan karakteristik lahan gambut yang terdegradasi sehingga menyebabkan penurunan fungsi ekologi, ekonomi, dan sosial dari lahan gambut (Masganti, Nurhayati, Yusuf, \& Widyanto, 2015). Untuk itu diperlukan upaya untuk mengembalikan fungsi ekosistem dari lahan gambut yang terdegradasi tersebut.

Upaya untuk mengembalikan fungsi ekosistem lahan gambut yang terdegradasi dapat dilakukan melalui beberapa cara yakni suksesi alami, restorasi hidrologis, rehabilitasi vegetasi, dan/atau cara lain sesuai dengan perkembangan ilmu pengetahuan dan teknologi (KemenLHK, 2017). Dalam penelitian ini, upaya pengembalian ekosistem lahan gambut yang terdegradasi dilakukan dengan rehabilitasi vegetasi. Rehabilitasi vegetasi dilakukan pada areal yang mengalami degradasi dengan mengutamakan jenis asli gambut dan mempertimbangkan kesesuaian lahan, aspek lingkungan, aspek sosial, dan aspek ekonomi (KemenLHK, 2017). Untuk mengakomodir aspek-aspek tersebut, maka dalam penetapan pola untuk rehabilitasi vegetasi perlu menganalisis kondisi sosial ekonomi masyarakat, preferensi masyarakat, karakteristik lahan gambut, karakteristik, dan pertimbangan teknis dan ekonomi dari jenis tanaman asli gambut serta status dan fungsi dari kawasan di mana akan dilakukan rehabilitasi vegetasi.

Karakteristik masyarakat di sekitar HLG yang didominasi oleh masyarakat pendatang sesungguhnya dapat menjadi pendorong perekonomian dan memotivasi transformasi sosial, tata nilai dari suatu daerah ke arah positif (Pranadji, \& Hastuti, 2017). Masyarakat pendatang akan berusaha terus menerus untuk bertahan hidup dengan penetrasi sosial dan berusaha mendapatkan kepemilikan sumberdaya alam dan faktor produksi lainnya termasuk lahan. Hal ini didukung oleh mata pencaharian utama penduduk di sekitar HLG Sungai Bram Itam yang sebagian besar merupakan petani. Pendapatan dari hasil kegiatan perkebunan terutama sawit, pinang, kopi, dan kelapa memberikan kontribusi sebesar $67,48 \%$ dari total pendapatan rumah tangga petani (Irawanti et al., 2017). Hal ini menunjukkan bahwa masyarakat yang tinggal di sekitar HLG Sungai Bram Itam memiliki mata pencaharian utama berbasiskan lahan, sehingga sumber daya lahan merupakan faktor yang penting dalam penghidupan masyarakat. Lahan merupakan faktor produksi utama dan diharapkan menjadi aset bagi keluarga petani (Ariendi, \& Kinseng, 2011).

Struktur masyarakat di sekitar HLG Sungai Bram Itam merupakan generasi keturunan dari pendahulunya sehingga mengindikasikan adanya kebutuhan baru terhadap lahan garapan. Lahan garapan yang dibuka oleh orang tua pendahulunya saat ini masih dalam posisi dikerjakan oleh orang tuanya atau sudah dibagibagikan kepada saudara yang lain. Kondisi lahan yang demikian tidak akan mencukupi untuk memenuhi kebutuhan hidup masyarakat pada generasi selanjutnya. Dengan demikian, mereka berusaha mencari lahan garapan baru. Meningkatnya jumlah penduduk dan kebutuhan pangan, mengakibatkan 
semakin meningkat pula kebutuhan lahan untuk pengembangan pertanian (Mulyani et al., 2013). Peningkatan kebutuhan lahan tersebut sulit dipenuhi dari lahan milik (lahan dari luar kawasan hutan) karena harus diperoleh dengan membeli atau menyewa.

Beberapa faktor antara lain: keterbatasan jumlah sumber daya manusia pengelola kawasan hutan, tidak adanya rambu-rambu yang menunjukkan bahwa HLG Sungai Bram Itam merupakan kawasan hutan, tidak adanya batas kawasan hutan yang jelas, fokus pengelolaan hutan pada masa itu hanya pada kawasan hutan produksi menjadikan kawasan HLG Sungai Bram Itam menjadi areal yang open access. Kondisi tersebut ditambah dengan anggapan dari pihak pemerintah daerah bahwa kawasan HLG Sungai Bram Itam adalah lahan tidur yang bisa dimanfaatkan untuk kegiatan pertanian. Beberapa faktor tersebut menjadi pendorong bagi masyarakat untuk masuk dan menggarap kawasan HLG Sungai Bram Itam.

Karakteristik lahan gambut di HLG Sungai Bram Itam yang beragam baik kedalaman, tingkat kematangan gambut maupun tinggi muka airnya, memerlukan tindakan pengelolaan yang sesuai dengan karakteristik biofisik, agroklimat, dan sosial masyarakat setempat; dan tidak harus sama dengan tempat yang lain. Karakteristik lahan gambut sangat ditentukan oleh ketebalan gambut, substratum atau tanah mineral di bawah gambut, kematangan, dan ada tidaknya pengayaan dari luapan sungai di sekitarnya (Subiksa, Hartatik, \& Agus, 2011). Di samping itu, pengelolaan lahan gambut diatur dan diarahkan secara terpadu dalam satu kesatuan pengelolaan untuk mengeliminasi dampak yang timbul pada kawasan tersebut maupun daerah sekitarnya (Noor, Nursyamsi, Alwi, \& Fahmi, 2014). Untuk mewujudkan pengelolaan lahan gambut secara terpadu dengan mempertimbang-kan karakteristik lahan gambut, maka diperlukan pengaturan zonasi pengelolaan lahan di kawasan HLG Sungai Bram Itam sebagai berikut:

a. Lahan gambut dengan kedalaman gambut $<1 \mathrm{~m}$ (gambut dangkal) dapat dimanfaatkan masyarakat untuk budidaya tanaman perkebunan dan pertanian deingan sistem agroforestri. Lahan gambut dangkal memiliki tingkat kesuburan relatif lebih tinggi dan risiko lingkungan lebih rendah dibandingkan gambut dalam (Subiksa et al., 2011). Pembukaan lahan gambut dangkal harus disertai dengan pengaturan air agar tanaman dapat tumbuh dengan baik. Oleh karena itu, perlu dilakukan pembuatan pintu-pintu air untuk mengatur muka air sehingga tanah dapat dipertahankan tetap basah atau lembab (moist) (Noor et al., 2014).

b. Lahan gambut dengan kedalaman gambut lebih dar $1 \mathrm{~m}$ sampai $3 \mathrm{~m}$ ) dikelola oleh pihak KPH untuk memperbaiki dan mempertahankan fungsi lindung dengan dilakukan pemulihan tutupan lahan. Pemanfaatan diperbolehkan untuk budidaya tanaman HHBK dan jasa lingkungan.

c. Lahan gambut dengan kedalaman gambut $>3 \mathrm{~m}$ ) juga dikelola oleh KPH dan diarahkan untuk zona lindung yang sama sekali tidak boleh dimanfaatkan.

Dalam Rencana Jangka Panjang Pengelolaan Hutan (RPHJP) KPHL Sungai Bram Itam telah memuat zonasi kawasan yang terdiri dari blok inti dan blok pemanfaatan (KPHL, 2017). Blok inti berfungsi sebagai perlindungan tata air dan perlindungan lainnya serta tidak untuk dimanfaatkan. Blok pemanfaatan dilakukan pemanfaatan oleh KPHL dan masyarakat. Dengan demikian, rencana pengelolaan KPHL Sungai Bram Itam telah diakomodir masyarakat dalam pengelolaan kawasan. 
Kawasan HLG Sungai Bram Itam mempunyai luas areal 15.050 ha dan \pm 5.000 ha diantaranya telah dikelola oleh masyarakat. Kondisi tersebut akan terus berlangsung mengingat kebutuhan terhadap lahan baik untuk pemukiman maupun garapan terus bertambah seiring bertambahnya populasi penduduk. Pertumbuhan penduduk yang tinggi dan terbatasnya lahan mendorong terjadinya alih fungsi lahan gambut menjadi lahan pertanian, industri kertas, pengembangan bioenergi, serta permukiman (Napitupulu, \& Mudian, 2015). Jika hal ini dibiarkan, maka alih fungsi kawasan HLG Sungai Bram Itam akan semakin bertambah luas, sehingga akan meningkatkan degradasi lahan gambut.

Upaya pengembalian fungsi ekosistem gambut dilakukan bersamaan dengan upaya untuk menahan terjadinya degradasi kawasan. Salah satu upaya pengembalian fungsi ekosistem lahan gambut adalah melalui rehabilitasi vegetasi. Rehabilitasi dilakukan dengan penanaman kembali dengan jenis-jenis tanaman asli di rawa gambut atau dengan jenis tanaman lain yang adaptif terhadap lahan basah (KemenLHK, 2017), sehingga dapat tumbuh dengan optimal tanpa upaya drainase.

Pemilihan jenis untuk rehabilitasi juga harus mempertimbangkan kebutuhan masyarakat karena kawasan HLG Sungai Bram Itam sudah menjadi bagian dari mata pencaharian masyarakat. Oleh karena itu, dalam kegiatan pemulihan ekosistem gambut perlu memperhatikan aspek sosial ekonomi masyarakat sekitar dan memberikan peluang bagi peningkatan pendapatan masyarakat sekitar hutan, diantaranya melalui kegiatan agroforestri (Biancalani \& Avagyan, 2014). Pengembangan komoditas aneka usaha kehutanan dengan pola agroforestri mampu meningkatkan pendapatan masyarakat secara signifikan dan sekaligus merehabilitasi lahan yang terdegradasi (Suharti, 2015). Untuk itu jenis-jenis yang digunakan untuk rehabilitasi harus memperhatikan keinginan masyarakat. Hal ini dilakukan dengan penggalian preferensi terhadap jenis yang ingin dikembangkan dalam kegiatan rehabilitasi vegetasi. Penggalian preferensi bertujuan untuk melihat persepsi masyarakat terhadap suatu jenis yang didasarkan pada nilai ekonomi dari tanaman tersebut dengan harapan masyarakat bersedia melakukan penanaman jenis tersebut.

Preferensi masyarakat terhadap tanaman kayu lebih mengarah pada tanaman yang menghasilkan buah seperti matoa (P. pinnata), rambutan (N. lappaceum), mangga (M. indica), duku (L. parasiticum), manggis (G. mangostana), pala (M. fragrans), jengkol (A. pauciflorum), kemiri (A. moluccanus), petai (P. speciosa), dan durian (D. zibethinus). Masyarakat di sekitar HLG Sungai Bram Itam sudah tidak mengetahui jenis-jenis tanaman asli lahan gambut, sehingga agak kesulitan ketika memilih preferensi untuk tanaman kehutanan. Pada umumnya mereka hanya menyebutkan jenis jelutung karena jenis tersebut biasanya digunakan oleh Dinas Kehutanan terkait untuk kegiatan penanaman di lahan gambut. Kesulitan dalam menentukan preferensi tanaman kehutanan disebabkan tanaman asli gambut sudah sangat jarang dijumpai di kawasan HLG Sungai Bram Itam. Tanaman asli gambut hanya bisa dijumpai di zona lindung HLG Sungai Bram Itam dan lokasinya sangat jauh masuk ke dalam kawasan. Di samping itu, masyarakat enggan menanam pohon yang hanya menghasilkan kayu karena adanya ketentuan bahwa pada kawasan lindung hanya boleh melakukan pemungutan hasil hutan bukan kayu. Seperti halnya pada petani hutan rakyat, bahwa alasan utama menanam pohon adalah karena faktor ekonomi seperti: untuk tabungan jangka panjang, menambah penghasilan, dan memenuhi kebutuhan sendiri (Achmad, Simon, Diniyati, Widyaningsih, Agroforestry, \& Km,, 2012). 
Jenis tanaman perkebunan yang menjadi preferensi masyarakat adalah pinang (A. catechu), kopi liberika (C. liberica), sawit (E. guineensis), dan kelapa hibrida (C. nucifera). Preferensi tersebut didasarkan pada pertimbangan pasar dan kecepatan untuk dijual daripada kondisi biofisik lahan. Masyarakat akan menanam komoditas yang sedang menjadi trend karena mudah mengakses pasarnya tanpa mempertimbangkan faktor biofisik lahan (Irawanti et al., 2017). Dari keempat komoditi di atas, hasil dari sawit yang pasarnya paling mudah dan paling cepat untuk dijual tanpa harus diolah. Sawit hanya memerlukan waktu satu hari atau langsung bisa dijual setelah dipanen, pinang membutuhkan waktu tiga sampai lima hari untuk bisa dijual sedangkan kopi membutuhkan waktu \pm 15 hari untuk bisa dijual.

Meskipun masyarakat telah memilih tanaman jenis pertanian dan perkebunan sesuai dengan keinginan yang didasarkan pada kebutuhan, tetapi tidak semua tanaman yang dipilih tersebut dapat diakomodir. Kelapa sawit adalah salah satu tanaman yang tidak dapat diakomodir dalam kegiatan rehabilitasi vegetasi. Aktivitas pembukaan dan pembersihan lahan (land clearing) dan pembuatan saluran (drainase) menyebabkan terjadinya perubahan tata air (Suwondo, Sabiham, Sumardjo, \& Paramudya, 2012). Kondisi tersebut berpengaruh pada terjadinya perubahan tingkat kesuburan lahan, penurunan muka tanah (subsidensi), dan dapat menimbulkan kering tidak balik (irreversibel drying) (Las, Nugroho, \& Hidayat, 2009) yang pada akhirnya mengganggu fungsi ekologi sebagai fungsi utama dari HLG Sungai Bram Itam.

Penanaman komoditi cepat menghasilkan (cash crops) penting untuk dilakukan mengingat tanaman perkebunan membutuhkan waktu beberapa tahun untuk berproduksi. Preferensi masyarakat terhadap cash crops antara lain: jahe (Zingiber officinale Roscoe), lengkuas (Alpinia galanga (L.) Willd.), nenas (Ananas comosus (L.) Merr.), dan daun ubi (cassava leaves). Pemilihan tersebut lebih didasarkan pada jenis yang kurang disukai oleh hama pengganggu seperti babi, monyet, dan tikus. Jenis cash crops hanya ditanam dalam jangka waktu tiga tahun pertama dari penanaman komoditi utama. Kendala penanaman cash crops adalah ketentuan pemanfaatan hutan lindung yang hanya boleh melakukan pengolahan tanah secara terbatas. Tetapi hasil penelitian yang dilakukan oleh Supangat (2013) menyatakan bahwa pemanfaatan lahan di bawah tegakan hutan lindung gambut untuk pertanian semusim tidak berpengaruh secara nyata terhadap penurunan kualitas air sungai. Namun dengan tingkat kepekaan tanah gambut yang sangat tinggi, maka pemanfaatan intensif atau pembukaan lahan yang eksploitatif sering menimbulkan masalah sifat fisika maupun kimia lahan (Noor et al., 2014). Dengan demikian, pemilihan cash crops diarahkan pada tanaman yang bersifat tahunan dengan pengolahan tanah yang terbatas.

Dari tabulasi hasil penelitian dan hasil inventarisasi serta penapisan terhadap ketersediaan dan harga bibit didapatkan bahwa jenis jelutung rawa, punak, meranti, balangeran, kelat, medang putih, medang mangga, laban, manggismanggisan, dan jambu-jambu merupakan jenis pohon asli gambut yang bisa digunakan untuk rehabilitasi vegetasi. Namun nilai ekonomi jenis-jenis tersebut kecuali jelutung terletak pada hasil kayunya. Hal ini tidak selaras dengan pemanfaatan pada kawasan lindung. Jelutung bisa dimanfaatkan getahnya, namun saat ini nilai ekonomi getah jelutung sudah tidak ada. Dengan demikian, perlu ditinjau kembali penanaman jenis-jenis tersebut pada kegiatan pemulihan fungsi ekosistem pada 
lahan gambut yang telah dimanfaatkan oleh masyarakat.

Mempertimbangkan hal-hal tersebut, maka rehabilitasi vegetasi pada areal yang telah dimanfaatkan masyarakat dapat mengakomodir jenis tanaman serba guna (Multi Purpose Trees Species/MPTS). Pada lahan yang dikelola oleh pihak KPHL dapat mempergunakan tanaman yang merupakan jenis asli gambut. Karakteristik lahan gambut merupakan acuan dalam pemanfaatan lahan gambut untuk mencapai produktivitas yang tinggi dan berkelanjutan (Subiksa et al., 2011). Lahan gambut untuk budidaya tanaman pangan adalah gambut dangkal (kedalaman gambut $<1 \mathrm{~m}$ ), ,untuk perkebunan pada gambut dengan kedalaman gambut $<3 \mathrm{~m}$, sedangkan gambut dengan kedalaman $>3 \mathrm{~m}$ lebih baik dihutankan atau untuk areal konservasi (BBPPSLP, 2008).

Pola pengelolaan lahan dengan teknik agroforestri perlu diterapkan dalam rehabilitasi vegetasi untuk mengembalikan fungsi ekosistem gambut di HLG Sungai Bram Itam. Agroforestri dipandang sebagai penyediaan layanan ekosistem, manfaat lingkungan, dan komoditas ekonomi sebagai bagian dari penggunaan yang multi fungsi dari lahan (Jose, 2009). Fungsi ekologi kawasan diperoleh dari tanaman kehutanan dan fungsi ekonomi diperoleh dari tanaman perkebunan/pertanian. Adanya ketentuan bahwa diakhir tahun ketiga dari kegiatan rehabilitasi vegetasi, jumlah tanaman yang sehat berjumlah lima ratus batang per hektar (KemenLHK, 2017). Dengan demikian, komposisi dan jarak tanam antara tanaman kehutanan dengan tanaman perkebunan diatur sedemikian rupa, sehingga fungsi ekonomi dan ekologi dapat berjalan seimbang.

Berdasarkan analisis aspek-aspek di atas, maka tanaman yang digunakan untuk rehabilitasi vegetasi pada lahan yang sudah dikelola masyarakat yaitu pinang, kopi liberika, jengkol, dan durian. Pinang, kopi liberika, jengkol, dan durian merupakan preferensi masyarakat. Tanaman pinang dan kopi liberika merupakan bentuk kearifan lokal terkait budidaya di lahan gambut oleh masyarakat sesuai dengan amanat Peraturan Pemerintah No. 57 Tahun 2016 tentang Perubahan atas Peraturan Pemerintah No. 71 Tahun 2014 tentang Perlindungan dan Pengelolaan Ekosistem Gambut. Tanaman pinang dan kopi liberika tersebut telah dibudidayakan oleh masyarakat, memiliki nilai ekonomi tinggi dan dalam pengelolaannya selaras dengan pengelolaan kawasan lindung. Tanaman durian dan jengkol merupakan jenis MPTS yang memiliki fungsi konservasi tanah dan air karena memiliki perakaran yang dalam. Serasah yang dihasilkan dari kedua jenis tanaman tersebut diharapkan mampu meningkat-kan kesuburan tanah. Tanaman jengkol merupakan komoditi tanaman buah yang sesuai ditanam pada lahan gambut dangkal (BBPPSLP, 2008), demikian juga durian (Nasrul, 2010). Durian ditanam dengan jarak $7 \times 7 \mathrm{~m}$ sampai $10 \times 10$ m karena berukuran besar sehingga perkembangan tajuk atau cabang-cabang lateral tidak saling mengganggu (Gaol, Purwoko, \& Affandi, 2015)

Pada lahan gambut dengan kedalaman kurang dari $2 \mathrm{~m}$ dan berdekatan dengan lahan masyarakat dapat menerapkan program perhutanan sosial dengan skema kemitraan. Kondisi lahan gambut seperti ini bisa menerapkan pola tanam agroforestri dengan menanam campuran antara tanam jenis kehutanan yang cocok di lahan gambut dengan tanaman perkebunan seperti pinang, kopi liberika, durian, jengkol. Pada daerah dengan kedalaman $\geq 2 \mathrm{~m}$, direhabilitasi dengan jenis tanaman asli gambut. Berikut pola-pola rehabilitasi vegetasi yang dapat dilakukan pada lahan gambut di HLG Sungai Bram Itam. 
a. Pola rehabilitasi vegetasi pada lahan dengan kedalaman gambut $<2 \mathrm{~m}$ yang secara existing sudah ada tanaman pertanian/perkebunan sebagai berikut:

- Pola 1, yakni pola rehabilitasi vegetasi pada lahan yang secara existing sudah ada tanaman sawit secara mono-kultur, maka dilakukan penyisipan jenis MPTS. Penyisipan dimulai dengan tanaman jengkol sejumlah seratus batang pada tahun ke-8. Penyisipan dengan tanaman durian sejumlah lima puluh batang pada tahun ke-9. Tanaman jengkol dan durian dapat disisipkan diantara tanaman sawit ( Maryunika, 2015; Teuscher et al., 2016; Gérard et al., 2017). Kemudian dilanjutkan dengan penyisipan pinang sejumlah 350 batang pada tahun ke-10. Pada pola ini tidak dilakukan pengurangan tanaman sawit melalui kegiatan penebangan, tetapi dibiarkan melalui mekanisme alami mengingat bearing capacity lahan gambut yang rendah sehingga tanaman akan mudah tumbang (BBPPSLP, 2008). Selanjutnya tanaman sawit tidak ditanam lagi, dan hanya jenis MPTS dan tanaman kehutanan pada rotasi berikutnya.

- Pola 2, yakni pola rehabilitasi vegetasi pada lahan yang secara existing sudah ada penanaman sawit campur dengan pinang. Pada pola ini, tanaman sawit secara perlahan akan dihilangkan. Penyisipan diawali dengan tanaman jengkol dan pinang pada tahun ke-10, masing-masing sejumlah seratus batang. Penyisipan dengan tanaman durian sejumlah lima puluh batang pada tahun ke-11. Penyisipan pinang sesuai dengan jumlah tanaman pinang yang mati/roboh pada tahun ke-12. Rotasi berikutnya yang ditanami tanaman kehutanan dan pinang saja.

- Pola 3, yakni pola rehabilitasi vegetasi pada lahan yang secara existing sudah ada penanaman pinang monokultur.
Rehabilitasi vegetasi dilakukan dengan menyisipkan tanaman jengkol, durian dan/atau tanaman kehutanan, masingmasing sejumlah lima puluh batang pada tahun ke-10.

- Pola 4, yakni rehabilitasi vegetasi pada lahan yang secara existing sudah ada penanaman pinang dicampur dengan kopi. Rehabilitasi vegetasi dilakukan dengan menyisipkan tanaman jengkol, durian dan/atau tanaman kehutanan masing-masing sebanyak lima puluh batang pada tahun ke-10.

b. Pola rehabilitasi vegetasi lahan gambut dengan kedalaman $<2$ m pada lahan yang masih kosong

Pola rehabilitasi vegetasi pada lahan kosong dilakukan dengan menanam komoditi yang dikembangkan secara bersama-sama di awal pengelolaan lahan disajikan pada Tabel 9.

c. Pola rehabilitasi pada lahan gambut dengan kedalaman lebih dari 2 meter

Kawasan gambut dengan kedalaman 2 - 3 m dikelola oleh pihak KPHL Sungai Bram Itam untuk memperbaiki dan mempertahankan fungsi lindung yang dapat dilakukan pemanfaatan HHBK dan jasa lingkungan, sehingga dapat dilakukan rehabilitasi vegetasi dengan jenis asli gambut misalnya dengan tanaman jelutung, ramin, balangeran, dan lain-lain. Jelutung merupakan tanaman asli gambut yang dapat dimanfaatkan getahnya dan pernah memiliki nilai ekonomi (Harun, 2016; Budiningsih, , \& Effendi, 2017). Ramin dan balangeran merupakan jenis yang kayunya memiliki nilai ekonomi tinggi dan saat ini sudah mulai langka sehingga penanaman jenis-jenis tersebut nantinya diharapkan menjadi sebagai sumber benih untuk kegiatan pemulihan fungsi ekosistem gambut. Pada lahan gambut dengan kedalaman lebih dari $3 \mathrm{~m}$ dijadikan kawasan lindung dan tidak untuk dimanfaatkan. 
Dhany Yuniati, Dodik Ridho Nurrochmat, Syaiful Anwar dan Darwo

Tabel (Table) 8. Komposisi tanaman untuk rehabilitasi vegetasi pada lahan yang sudah ada tanaman di HLG Sungai Bram Itam (Composition of plants for rehabilitation of vegetation on farm land with existing agricultural crops/plantations in protected peatland forest of Sungai Bram Itam)

\begin{tabular}{|c|c|c|c|c|c|}
\hline \multirow{3}{*}{$\begin{array}{l}\text { Pola rehabilitasi } \\
\text { (Pattern of } \\
\text { rehabilitation })\end{array}$} & \multicolumn{5}{|c|}{ Komposisi (Composition) } \\
\hline & \multirow{2}{*}{$\begin{array}{c}\text { Sawit } \\
\text { (palm } \\
\text { oil) } \\
\text { (Batang/ } \\
\text { Stand) }\end{array}$} & \multirow{2}{*}{$\begin{array}{c}\text { Pinang } \\
\text { (areca } \\
\text { nut) } \\
\text { (Batang/ } \\
\text { (Stand) }\end{array}$} & \multirow{2}{*}{$\begin{array}{l}\text { Kopi liberika } \\
\text { (liberica coffee) } \\
\text { (Batang/Stand) }\end{array}$} & \multicolumn{2}{|c|}{$\begin{array}{c}\text { MPTS (Multi purpose tress species) } \\
\text { (Batang/Stand) }\end{array}$} \\
\hline & & & & $\begin{array}{c}\text { Jengkol (Archidendron } \\
\text { pauciflorum) }\end{array}$ & $\begin{array}{c}\text { Durian(Durio } \\
\text { zibethinus) }\end{array}$ \\
\hline Pola 1 & 80 & 350 & - & 100 & 50 \\
\hline Pola 2 & - & 595 & - & 100 & 50 \\
\hline Pola 3 & - & 1.000 & - & 50 & 50 \\
\hline Pola 4 & - & 580 & 500 & 50 & 50 \\
\hline
\end{tabular}

Sumber (Source): Hasil analisis (Analysis result)

Tabel (Table) 9. Komposisi tanaman untuk rehabilitasi vegetasi pada lahan kosong di HLG Sungai Bram Itam (Composition of plants for rehabilitation of vegetation on emptyland in protected peatland forest of Sungai Bram Itam)

\begin{tabular}{|c|c|c|c|c|c|}
\hline \multirow{2}{*}{\multicolumn{2}{|c|}{$\begin{array}{c}\text { Pola rehabilitasi } \\
\text { (Pattern of rehabilitation) }\end{array}$}} & \multicolumn{4}{|c|}{$\begin{array}{c}\text { Komposisi } \\
\text { (Composition) }\end{array}$} \\
\hline & & $\begin{array}{l}\text { Jengkol }(A . \\
\text { pauciflorum) } \\
\text { (Batang/ } \\
\text { Stand) }\end{array}$ & $\begin{array}{l}\text { Durian }(D . \\
\text { zibethinus) } \\
\text { (Batang/ } \\
\text { Stand) }\end{array}$ & $\begin{array}{l}\text { Kopi } \\
\text { liberika }(C . \\
\text { liberica) } \\
\text { (Batang/ } \\
\text { Stand })\end{array}$ & $\begin{array}{l}\text { Pinang } \\
\text { (Areca nut) } \\
\text { (Batang/ } \\
\text { Stand) }\end{array}$ \\
\hline 1. & $\begin{array}{l}\text { Pinang (A. catechu), jengkol (A. } \\
\text { pauciflorum), durian (D. } \\
\text { zibethinus), nenas (A. comasus), } \\
\text { jagung (Z. mays), daun ubi } \\
\text { (Cassava leaves) }\end{array}$ & 100 & 50 & - & 550 \\
\hline 2. & $\begin{array}{l}\text { Kopi liberika (C. liberica), } \\
\text { jengkol (A. pauciflorum), durian } \\
\text { (D. zibethinus), jagung (Z. mays) }\end{array}$ & 100 & 50 & 550 & - \\
\hline 3. & $\begin{array}{l}\text { Pinang (A. nut), kopi liberika (C. } \\
\text { liberica), jengkol (A. } \\
\text { pauciflorum), durian (D. } \\
\text { zibethinus), jagung (Z. mays) }\end{array}$ & 100 & 50 & 275 & 275 \\
\hline
\end{tabular}

Sumber (Source): Hasil analisis (Analysis result)

\section{KESIMPULAN DAN SARAN}

\section{A. Kesimpulan}

Masyarakat di sekitar HLG Sungai Bram Itam membutuhkan lahan garapan untuk dikelola. Status HLG Sungai Bram Itam sebagai kawasan dengan fungsi lindung dan memiliki karakteristik lahan yang beragam memerlukan penataan zonasi pengelolaan untuk memfasilitasi kebutuhan masyarakat terhadap lahan. Pada kawasan dengan kedalaman gambut kurang dari $2 \mathrm{~m}$ dan berdekatan dengan batas lahan masyarakat, maka dapat dilakukan program perhutanan sosial dengan menerapkan skema kemitraan. Kondisi lahan seperti ini bisa diterapkan pola tanam agroforestri yaitu penanaman jenis tanaman kehutanan dengan tanaman perkebunan (kopi liberika, pinang dan jenis MPTS) yang tetap memperhatikan fungsi lindung yaitu konservasi tanah dan air. Pada lahan gambut dengan kedalaman lebih dari $2 \mathrm{~m}$ dikelola oleh pihak KPHL 
Dhany Yuniati, Dodik Ridho Nurrochmat, Syaiful Anwar dan Darwo

Sungai Bram Itam untuk mempertahankan dan memperbaiki fungsi lindung dengan menanam jenis-jenis tanaman asli gambut.

\section{B. Saran}

Faktor pembatas penanaman jenis asli gambut adalah ketersediaan bibit baik jumlah maupun jenis, untuk itu perlu digalakkan pengadaan bibit untuk jenisjenis yang langka dan bernilai ekonomi tinggi seperti ramin dan balangeran Di samping itu perlu digalakkan penggunaan getah jelutung misalnya untuk resin dan kerajinan, sehingga pasar getah jelutung dapat ditemukan kembali dan tidak tergantung pada pasar ekspor.

\section{UCAPAN TERIMA KASIH}

Penelitian ini dibiayai DIPA Badan Restorasi Gambut tahun 2017. Penulis mengucapkan terima kasih kepada Tim peneliti gambut Pusat Penelitian dan Pengembangan Hutan, Staf KPHL Sungai Bram Itam yang telah membantu di lapanga, masyarakat desa Bram Itam Raya, Bram Itam Kanan, Mandala Jaya, Mekar Jaya, Bunga Tanjung dan Serdang Jaya yang telah menyediakan waktu untuk menjadi responden dalam penelitian ini dan semua pihak atas bantuannya dalam penulisan karya tulis ilmiah ini.

\section{DAFTAR PUSTAKA}

Achmad, B., Simon, H., Diniyati, D., Widyaningsih, T.S., Agroforestry, B.P.T., \& Km, J.C.B. (2012). Persepsi petani terhadap pengelolaan dan fungsi hutan rakyat di kabupaten ciamis. Jurnal Bumi Lestari, 12(1), 123-136.

Alpian, A., Prayitno, T.A., Pramana, J., Sutapa, G., \& Budiadi, B. (2014). Kualitas asap cair batang gelam (Melaleuca sp.). Jurnal Penelitian Hasil Hutan, 32(2), 83-92.

Ariendi, G.G.T., \& Kinseng, R.A. (2011). Strategi perjuangan petani dalam mendapatkan akses dan penguasaan atas lahan. Sodality: Jurnal Sosiologi Pedesaan, 5(1), 13-31.

BBPPSLP. (2008). Pemanfaatan dan Konservasi Ekosisten Lahan Rawa Gambut di Kalimantan. Tim Sintesis Kebijakan. Pengembangan Inovasi Pertanaian (Pros.), 149-156. Bogor.

Budiningsih, K., \& Effendi, R. (2017). Analisis kelayakan finansial hutan tanaman jelutung (Dyera polyphylla) di Kalimantan Tengah. Jurnal Penelitian Hutan Tanaman, 10(1), 17-23.

Darwo, Tata, M.H.L., Heriansyah, I., Nugroho, I.A., Bogidarmanti, R., Butarbutar, T., . . Mawazin. (2017). Implementasi Paludikultur dan Agroforestry di Lahan Gambut. Bogor (ID): Badan Restorasi Gambut dengan Pusat Penelitian dan Pengembangan Hutan, Badan Litbang dan Inovasi Kementerian Lingkungan Hidup dan Kehutanan.

Gaol, T.W.I.L., Purwoko, A., \& Affandi, O. (2015). Studi kelayakan ekonomi budidaya durian (Durio zibethinus Murr) rakyat di Desa Lau Bagot, Kecamatan Tigalingga, Kabupaten Dairi. Peronema Forestry Science Journal, 4(3), 331-338.

Gérard, A., Wollni, M., Hölscher, D., Irawan, B., Sundawati, L., Teuscher, M., \& Kreft, H. (2017). Oil-palm yields in diversified plantations: Initial results from a biodiversity enrichment experiment in Sumatra, Indonesia. Agriculture, Ecosystems \& Environment, 240, 253-260.

Giesen, W. (2015). Utilising non-timber forest products to conserve Indonesia's peat swamp forests and reduce carbon emissions. Journal of Indonesian Natural History, 3(2), 1019.

Harun, M.K. (2016). The development strategy of jelutung's latex as superior 
non timber forest product. Jurnal Hutan Tropis, 2(2), 138-145.

Irawanti, S., Surati, Handoyo, Mulyadin, Ariawan, K., Setiadi, A., \& Charity, D. (2017). Analisis mata pencaharian masyarakat di lahan gambut. Bogor (ID): Kerjasama Badan Restorasi Gambut dan Puslitbang Sosial Ekonomi Kebijakan dan Perubahan Iklim.

Jose, S. (2009). Agroforestry for ecosystem services and environmental benefits: an overview. Agroforestry Systems, 76(1), 1-10.

Karim, A., Tie, A., Manan, D., \& Zaidul, I. (2008). Starch from the sago (Metroxylon sagu) palm tree properties, prospects, and challenges as a new industrial source for food and other uses. Comprehensive Reviews in Food Science and Food Safety, 7(3), 215-228.

KemenLHK. (2017). Permen LHK No. P.16/MenLHK/Setjen/Kum.1/2/2017 Tentang Pedoman Teknis Pemulihan Fungsi Ekosistem Gambut. Jakarta: Sekretariat Jendral.

KPHL. (2017). Rencana Pengelolaan Hutan Jangka Panjang (RPHJP) Kesatuan Pengelolaan Hutan Unit XVII KPHL Model Sungai Beram Hitam Tahun 2018 - 2027. Tanjung Jabung Barat: KPHL Sungai Bram Itam.

Las, K., Nugroho, \& Hidayat, A. (2009). Strategi pemanfaatan lahan gambut untuk pengembangan pertanian berkelanjutan. Pengembangan Inovasi Pertanian, 2(4), 295-298.

Maryunika, R. (2015). Strategi Pengelolaan dan Pengembangan Agroforestri Berbasis Kelapa Sawit di Jambi. Master's thesis, University of Bogor, Bogor.

Masganti, M., Nurhayati, N., Yusuf, R., \& Widyanto, H. (2015). Teknologi ramah lingkungan dalam budidaya kelapa sawit di lahan gambut terdegradasi. Jurnal Sumberdaya Lahan, 9(2), 97-106.

Mulyani, A., \& Sarwani, M. (2013). Karakteristik dan potensi lahan sub optimal untuk pengembangan pertanian di Indonesia. Jurnal Sumberdaya Lahan, 7(1).

Napitupulu, S.M., \& Mudian, B. (2015). Pengelolaan sumber daya air pada lahan gambut yang berkelanjutan, 1, 330-337. Pekanbaru (ID): Annual Civil Engineering Seminar.

Nasrul, B. (2010). Penyebaran dan potensi lahan gambut di Kabupaten Bengkalis untuk pengembangan pertanian. Jurnal Agroteknologi, 1(1), 1-7.

Noor, M., Nursyamsi, D., Alwi, M., \& Fahmi, A. (2014). Prospek pertanian berkelanjutan di lahan gambut: dari petani ke peneliti dan peneliti ke petani. Jurnal Sumberdaya Lahan, 8(2), 69-79.

Posa, M.R.C., Wijedasa, L.S., \& Corlett, R.T. (2011). Biodiversity and conservation of tropical peat swamp forests. BioScience, 61(1), 49-57.

Pranadji, T., \& Hastuti, E.L. (2017). Transformasi sosio-budaya dalam pembangunan pedesaan. Analisis Kebijakan Pertanian, 2(1), 77-92.

Prihatini, N.S., Priatmadi, B.J., Masrevaniah, A., \& Soemarno, S. (2016). Effects of the purun tikus (Eleocharis dulcis (Burm. F.) Trin. ex Hensch) planted in the Horizontal Subsurface Flow-Constructed Wetlands (HSSFCW) on iron (Fe) concentration of the acid mine drainage. Journal of Applied Environmental and Biological Sciences.

Schäfer, A. (2012). Paludiculture for biodiversity and climate-economics of rewetted peatlands. on Biodiversity and Climate Change-Science, Practice and Policy, 63. 
Sidiyasa, K. (2012). Karakteristik hutan rawa gambut di Tuanan dan Katunjung, Kalimantan Tengah. Jurnal Penelitian Hutan dan Konservasi Alam, 9(2), 125-137.

Sosilawaty, S., Yanarita, Y., \& Andrean, T. (2017). Analysis of vegetation in special purpose forest of Tumbang Nusa, Jabiren Raya Subdistrict, Central Kalimantan. Tropical Wetland Journal, 2(3), 11-14.

Subiksa, I., Hartatik, W., \& Agus, F. (2011). Pengelolaan lahan gambut secara berkelanjutan. Balai Penelitian Tanah. Balai Besar Penelitian dan Pengembangan Sumberdaya Lahan Pertanian. Badan Litbang Pertanian. Kementerian Pertanian. Bogor, 16.

Suharti, S. (2015). Peningkatan pendapatan masyarakat melalui budidaya komoditas aneka usaha kehutanan (AUK). Paper presented at the Prosiding Seminar Nasional Masyarakat Biodiversiti Indonesia.

Supangat, A.B. (2013). Pengaruh gangguan pada kawasan Hutan Lindung terhadap kualitas air sungai: Studi kasus di Provinsi Jambi (Effects of disturbances of protected Forest
Area on river water duality: Case study at Jambi Province). Indonesian Forest Rehabilitation Journal, 1(1), 75-89.

Suwondo, S., Sabiham, S., Sumardjo, S., \& Paramudya, B. (2012). Efek pembukaan lahan terhadap karakteristik biofisik gambut pada perkebunan kelapa sawit di Kabupaten Bengkalis. Jurnal Natur Indonesia, 14(2), 143-149.

Tata, H.L., \& Pradjadinata, S. (2017). Native species for degraded peat swamp forest rehabilitation. Jurnal Silvikultur Tropika, 7(3), 80-82.

Teuscher, M., Gérard, A., Brose, U., Buchori, D., Clough, Y., Ehbrecht, M., Wollni, M. (2016). Experimental biodiversity enrichment in oil-palmdominated landscapes in Indonesia. Frontiers in Plant Science, 7, 1538.

Yule, C.M. (2010). Loss of biodiversity and ecosystem functioning in IndoMalayan peat swamp forests. Biodiversity and Conservation, 19(2), 393-409. 